\title{
PENGEMBANGAN BUKU LECTORE INSPIRE UNTUK MENGEMBANGKAN KETERAMPILAN MAHASISWA DALAM MENGGUNAKAN MEDIA BERBASIS TIK DI IAIN TULUNGAGUNG
}

\author{
Dewi Asmarani \\ State Islamic Institusi of Tulungagung \\ Email: dewiasmarani.iain@gmail.com
}

\begin{abstract}
Abstrak. Tuntutan sebagai calon guru yang profesional dibidangnya merupakan salah satu alasan perlunya dikembangkan buku Lectora Inspire ini. Dengan dikembangkannya buku Lectora Inspire (LI) ini pengetahuan dan keterampilan IT mahasiswa Tadris Matematika IAIN Tulungagung dapat meningkat. Buku Lectora Inspire dikembangkan melalui beberapa tahap, yaitu: 1) tahap pendefinisian, 2) tahap perancangan, 3) tahap pengembangan, dan 4) tahap pendeseminasian. Hasil pengembangan yang diperoleh adalah buku Lectora Inspire yang disusun dengan cara ditulis, bahasanya mudah untuk dipahami, menarik, penuh dengan gambar dan keterangan-keterangannya, serta isi buku menggambarkan sesuatu yang sesuai dengan ide penulisnya.
\end{abstract}

Kata Kunci: Lectora Inspire, Media pembelajaran, TIK

\section{PENDAHULUAN}

Pemanfaatan media pembelajaran ataupun sumber belajar berbasis teknologi dan informasi (IT) sangat penting bagi guru maupun bagi siswa. Manfaat yang diperoleh dari penggunaan media IT adalah proses pembelajaran menjadi lebih menarik, mudah diterima, dapat meningkatkan motivasi siswa untuk belajar dimana saja dan kapan saja. Selain itu media pembelajaran juga dapat membantu guru untuk menyajikan materi yang bersifat abstrak menjadi lebih konkret sehingga mudah dipahami.

Mahasiswa Tadris matematika (TMT) merupakan calon-calon guru yang dididik untuk menjadi tenaga guru yang profesional, kompeten dibidangnya dan tidak gagap teknologi (gaptek). Mahasiswa TMT dituntut untuk menguasai beberapa software pembelajaran yang dikemas dalam mata kuliah Pembelajaran Berbasis TIK. Berdasarkan hasil survey peneliti terhadap mahasiswa TMT, untuk saat ini software pembelajaran yang mereka kuasai masih sangat terbatas yaitu word, power-point, excel, dan mapel. Kondisi tersebut tentunya masih jauh dari harapan. Harapan yang dimaksud adalah jika ditelusuri kembali masih banyak softwaresoftware terbaru dan mutakhir yang harus mereka kuasai seperti Autoplay, Geogebra, Lectora Inspire dan lain-lain. Keterbatasan yang terjadi tentunya menjadi masalah tersendiri yang harus diselesaikan. Untuk itu perlu adanya inovasi baru yang dapat mengembangkan keterampilan mereka dalam menggunakan media berbasis TIK (Teknologi Informasi Komputer).

Salah satu inovasi yang dapat dilakukan adalah dengan mengembangkan suatu buku tentang pemanfaatan software dalam pembelajaran. Salah satu software yang ditawarkan adalah software Lectora Inspire.

\section{Lectora Inspire}

Lectora Inspire adalah Authoring Tool untuk pengembangan konten e-learning yang dikembangkan oleh Trivantis Corporation. Lectora Inspire mampu membuat kursus online cepat dan sederhana. Pendirinya adalah Timothy D. Loudermilk di Cincinnati, Ohio, Amerika tahun 1999. Tahun 2011, Lectora Inspire memperoleh 5 penghargaan dalam bidang produk e-learning inovatif, authoring tool, tool presentasi terbaik, dan teknologi e-learning terbaik. Sehingga wajar bila lebih dari 50 perusahaan atau instasi di dunia memilih Lectora Inspire.

Menurut Mas'ud (2014) program Lectora Inspire ini didukung beberapa fitur yang sangat menunjang untuk penyusunan media pembelajaran. Fitur-fitur tersebut antara lain sebagai berikut:

1. Flypaper ${ }^{\mathrm{TM}}$ for Lectora

Membuat pembelajaran lebih kreatif dengan menambah animasi flash, transisi dan efek spesial.

\section{Camtasia ${ }^{\circledR}$ for Lectora}

Membuat tutorial profesional dengan mudah, membuat video, animasi flash, software desain 
3D, mengedit video, audio, transisi, dan lainlain.

\section{Snagit $®$ for Lectora}

Membuat image dari tangkapan layar, dilengkapi dengan callout, dan lain-lain.

Berdasarkan fitur-fitur yang telah dijelaskan di atas maka dengan menggunakan program aplikasi Lectora Inspire kita dapat menyiapkan bahan ajar atau program presentasi maupun program aplikasi baru. Mas'ud (2014) juga menjelaskan bagi pengguna pemula disediakan fasilitas Title Wizard. Title Wizard yang terdapat dalam Lectora Inspire memiliki variasi template yang cukup banyak, sehingga user yang tergolong pemula dapat menggunakan template yang tersedia dengan mudah.

Kegunaan dan Kelebihan dari Lectora Inspire

Lectora Inspire mampu membuat kursus online dengan cepat dan sederhana. Bagi pemula, terdapat fitur title wizard yang digunakan untuk membuat kerangka title (judul) secara otomatis dengan menentukan style tampilan, jumlah chapter, page, test, serta tombol-tombol navigasi standar. title wizard yang terdapat dalam Lectora Inspire memiliki variasi template yang cukup banyak, sehingga pengguna pemula dapat menggunakan template yang tersedia dengan mudah. Selain itu, dalam software Lectora Inspire terdapat toolbar equation yang dapat digunakan dosen matematika menulis rumus-rumus matematika. Dari segi prestasi, Lectora Inspire telah memperoleh 5 penghargaan dalam bidang produk e-learning inovatif, authoring tool, tool presentasi terbaik, dan teknologi e-learning terbaik. Dari penjelasan tersebut tampak bahwa Lectora Inspire merupakan salah satu program aplikasi yang dapat digunakan untuk mepersiapkan bahan ajar, presentasi maupun program aplikasi baru.

\section{Arti Buku Teks}

Buku teks pelajaran adalah buku acuan wajib untuk digunakan di sekolah yang memuat materi pembelajaran dalam rangka peningkatan kemampuan penguasaan ilmu pengetahuan yang disusun berdasarkan standar nasional pendidikan. Menurut Chambliss dan Calfee, sebagaimana dikutip oleh Muslich (2010), buku teks adalah alat bantu siswa untuk memahami dan belajar dari hal-hal yang dibaca dan untuk memahami dunia (di luar dirinya). Sedangkan menurut Tarigan dan Tarigan (2009), buku teks adalah buku pelajaran dalam bidang studi tertentu yang disusun oleh para pakar dalam bidang itu untuk maksud-maksud dan tujuan instruksional, yang mudah dipahami oleh para pemakainya di sekolah sehingga dapat menunjang suatu program pengajaran. Berdasarkan pendapat tersebut, buku teks digunakan untuk mata pelajaran tertentu. Penggunaan buku teks tersebut berdasarkan tujuan pembelajaran yang mengacu pada kurikulum.

Buku teks memiliki kekuatan yang luar biasa besar terhadap perubahan otak siswa. Buku teks dapat mepengaruhi pengetahuan anak dan nilai-nilai tertentu. Indikator atau ciri penanda buku teks adalah sebagai berikut.

1. Buku teks merupakan buku sekolah yang ditujukan bagi siswa pada jenjang pendidikan tertentu.

2. Buku teks berisi bahan yang telah terseleksi.

3. Buku teks selalu berkaitan dengan bidang studi atau mata pelajaran tertentu.

4. Buku teks biasanya disusun oleh para pakar dibidangnya.

5. Buku teks ditulis untuk tujuan instruksional tertentu.

6. Buku teks biasanya dilengkapi dengan sarana pembelajaran.

7. Buku teks disusun secara sistematis mengikuti strategi pembelajaran tertentu.

8. Buku teks untuk diasimilasikan dalam pembelajaran.

9. Buku teks disusun untuk menunjang program pembelajaran.

Dari berbagai uraian di atas, dapat kita simpulkan bahwa buku teks merupakan buku sekolah yang ditujukan untuk siswa pada jenjang tertentu, memuat materi yang telah terseleksi mengenai bidang studi tertentu, yang disusun secara sistematis oleh pakar dibidangnya untuk maksud dan tujuan instruksional, dilengkapi dengan sarana pembelajaran yang mudah dipahami oleh pemakaiannya, sehingga dapat menunjang program pembelajaran.

\section{Teknik Pengembangan Buku Teks}

Pengembangan buku teks berarti mengajarkan suatu mata pelajaran melalui tulisan. Oleh karena itu, prinsip-prinsip yang digunakan dalam mengembangkan buku teks sama dengan yang digunakan dalam pembelajaran biasa. Bahasa buku teks bersifat sangat formal. 
Ada tiga teknik yang dapat dipilih dalam menyusun buku teks. Ketiga teknik tersebut menurut Sungkono, dkk. (2003), yaitu menulis sendiri, pengemasan kembali informasi, dan penataan informasi. Berikut adalah penjelasannya.

1) Menulis Sendiri (Starting from Scratch)

Penulis/guru dapat menulis sendiri buku teks yang akan digunakan dalam proses pembelajaran. Asumsi yang mendasari cara ini adalah bahwa guru adalah pakar yang berkompeten dalam bidang ilmunya, mempunyai kemampuan menulis, dan mengetahui kebutuhan siswa dalam bidang ilmu tersebut. Untuk menulis buku teks sendiri, disamping penguasaan bidang ilmu, juga diperlukan kemampuan menulis buku teks sesuai dengan prinsip-prinsip pembelajaran, yaitu selalu berlandaskan kebutuhan siswa, yang meliputi pengetahuan, keterampilan, bimbingan, latihan, dan umpan balik. Pengetahuan itu dapat diperoleh melalui analisis pembelajaran, dan silabus. Jadi, materi yang disajikan dalam buku teks adalah pokok bahasan dan sub pokok bahasan yang tercantum dalam silabus.

2) Pengemasan Kembali Informasi (Information Repackaging)

Penulis/guru tidak menulis buku teks sendiri, tetapi memanfaatkan buku-buku teks dan informasi yang telah ada di pasaran untuk dikemas kembali menjadi buku teks yang memenuhi karakteristik buku teks yang baik. Buku teks atau informasi yang sudah ada dikumpulkan berdasarkan kebutuhan (sesuai dengan kompetensi, silabus dan RPP/SAP), kemudian disusun kembali dengan gaya bahasa yang sesuai. Selain itu juga diberi tambahan keterampilan atau kompetensi yang akan dicapai, latihan, tes formatif, dan umpan balik.

3) Penataan Informasi (Compilation)

Cara ini mirip dengan cara kedua, tetapi dalam penataan informasi tidak ada perubahan yang dilakukan terhadap buku teks yang diambil dari jurnal ilmiah, artikel, dan lain-lain. Dengan kata lain, materi-materi tersebut dikumpulkan, digandakan dan digunakan secara langsung. Materi-materi tersebut dipilih, dipilah dan disusun berdasarkan kompetensi yang akan dicapai dan silabus yang hendak digunakan.

Buku teks yang baik menurut Majid (2011) adalah buku yang ditulis dengan menggunakan bahasa yang baik dan mudah dimengerti, disajikan secara menarik dan dilengkapi dengan gambar dan keteranganketerangannya. Isi buku juga menggambarkan sesuatu yang sesuai dengan ide penulisnya. Buku pelajaran berisi tentang ilmu pengetahuan yang dapat digunakan oleh siswa untuk belajar, sedangkan buku fiksi akan berisi tentang pikiran-pikiran fiksi penulisnya.

Melalui penelitian ini peneliti berusaha mengembangkan buku teks yang baik yang ditulis dengan menggunakan bahasa yang baik dan mudah dimengerti, disajikan secara menarik dan dilengkapi dengan gambar dan keteranganketerangannya, isi buku juga menggambarkan sesuatu yang sesuai dengan ide penulisnya.

\section{METODE}

Metode yang digunakan dalam penelitian ini adalah metode penelitian dan pengembangan atau Research and Development. Research and Development adalah metode penelitian yang digunakan untuk menghasilkan produk tertentu dan menguji keefektifan produk tersebut (Sugiyono, 2011).

Lokasi uji coba pengembangan Lectora Inspire yaitu di IAIN Tulungagung. Uji coba Buku Teks Lectora Inspire dilakukan pada mahasiswa tadris matematika IAIN Tulungagung. Model Pengembangan mengacu pada Four D (4D).

\section{HASIL DAN PEMBAHASAN}

\section{Pengembangan Buku Teks Lectora Inspire}

1. Tahap Pendefinisian (Define)

a. Analisis awal-akhir (front-end analysis)

Analisis awal dilakukan untuk mengumpulkan informasi tentang potensi dan permasalahan dalam perkuliahan mahasiswa TMT IAIN Tulungagung. Peneliti melakukan wawancara awal terhadap beberapa dosen TMT. Dari hasil wawancara dapat diketahui bahwa terdapat beberapa permasalahan dalam perkuliahan matematika, yaitu:

1) Belum adanya buku Lectora Inspire yang dapat digunakan sebagai bahan acuan dalam mengajar pembelajaran matematika berbasis IT

2) Mahasiswa belum menguasai software Lectora Inspire.

b. Analisis mahasiswa (learner analysis)

Mahasiswa adalah siswa dewasa yang cara berpikirnya berbeda dengan anak-anak usia sekolah. Di dalam belajar gaya merekapun berbeda pula. Ada kecenderungan mereka selalu 
belajar berkelompok atau individual. Selain itu mereka selalu mengidentifikasi karakteristik dosen dalam mengajar. Hal ini dilakukan agar mudah dalam mengikuti perkuliahan dengan baik. Mahasiswa belajar juga berdasarkan buku pedoman, soal, dan catatan. Oleh sebab itu perlu disusun buku Lectora Inspire sebagai pedoman dalam melaksanakan perkuliahan matematika berbasis IT .

c. Analisis tugas (task analysis)

Buku Lectora Inspire ini berisikan petunjuk atau cara-cara mengoperasikan software Lectora Inspire secara mandiri dan menantang. Mahasiswa secara otodidak akan langsung mempraktekkan software tersebut

d. Analisis konsep (concept analysis)

Konsep-konsep utama yang akan diajarkan di dalam Buku Lectora Inspire adalah pendahulan dari Lectora Inspire, aplikasi toolbar add object, aplikasi menu file, menyelipkan hyperlink, membuat materi uji soal, penskoran, aplikasi go to, mencari skor akhir .

e. Perumusan tujuan perkuliahan ((specifying instructional objectives)

Tujuan perkuliahan yang ingin dicapai setelah memakai buku teks ini adalah mahasiswa mampu dan terampil memanfaatkan program "Lectora Inspire" sebagai "alat bantu" mengajar matematika dengan memanfaatkan komputer.

2. Tahap Perancangan (Design)

Tujuan tahap ini adalah untuk menyiapkan prototipe buku teks. Tahap ini terdiri dari 4 langkah yaitu
a. mengonstruksi tes beracuan-kriteria (constructing criterion-referenced test).

Tes disusun berdasarkan hasil perumusan tujuan perkuliahan. Tes ini merupakan suatu alat yang mengukur terjadinya perubahan tingkah laku pada diri mahasiswa setelah kegiatan perkuliahan. Berikut adalah tes yang akan diberikan.

"Gunakan software Lectora inspire untuk menyusun sebuah bahan presentasi".

b. pemilihan media (media selection).

Pemilihan media yang sesuai dengan Buku Lectora Inspire adalah media komputer dengan program Lectora Inspire

c. pemilihan format (format selection).

Untuk format yang dipilih masih tetap sama dengan yang sebelumnya, hanya saja bahasanya berubah. Adapun format yang dipakai adalah:

1) Halaman judul

2) Identitas penerbit

3) Kata pengantar

4) Daftar isi

5) Isi

6) Daftar Pustaka

7) Tentang penulis

d. desain awal (initial design).

Desain awal dari Buku LI ini adalah:

1) Bagian depan

Bagian ini berisi:

a) Halaman judul

Untuk halaman judul yang diberikan berbentuk gambar berikut.

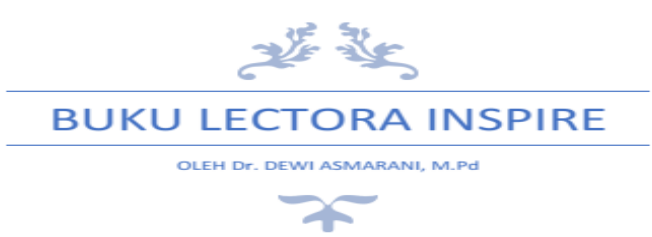

Gambar 1. Sampul Buku Lectora Inspire

b) Kata Pengantar

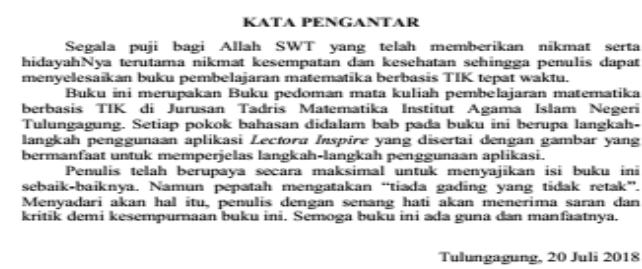

Gambar 2. Kata Pengantar Buku Lectora Inspire

c) Daftar Isi

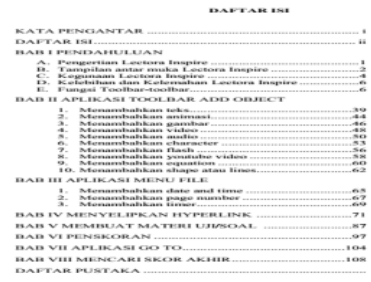

Gambar 3. Daftar Isi Buku Lectora Inspire

2) Bagian isi

a) Judul bab

Judul bab merupakan representasi dari isi bab tersebut. Buku LI ini terdiri atas $8 \mathrm{Bab}$, yaitu: 
BAB I PENDAHULUAN

BAB II APLIKASI TOOLBAR ADD OBJECT

BAB III APLIKASI MENU FILE

BAB IV MENYELIPKAN HYPERLINK

BAB V MEMBUAT MATERI UJI/SOAL

BAB VI PENSKORAN

BAB VII APLIKASI GO TO

BAB VIII MENCARI SKOR AKHIR

b) Judul subbab (sub title)

Judul subbab akan memberikan gambaran rincian dari bab yang akan dipelajari. Berikut rincian subbab dari masing-masing bab.

\section{BAB I PENDAHULUAN}

1. Pengertian Lectora Inspire

2. Tampilan antar muka Lectora Inspire

3. Kegunaan Lectora Inspire

4. Kelebihan dan Kelemahan Lectora Inspire

5. Fungsi Toolbar-toolbar

BAB II APLIKASI TOOLBAR ADD OBJECT

1. Menambahkan teks

2. Menambahkan animasi

3. Menambahkan gambar

4. Menambahkan video

5. Menambahkan audio

6. Menambahkan character

7. Menambahkan flash

8. Menambahkan video youtube

9. Menambahkan equation

10. Menambahkan shape atau lines

BAB III APLIKASI MENU FILE

1. Menambahkan date and time

2. Menambahkan page number

3. Menambahkan timer

BAB IV MENYELIPKAN HYPERLINK

BAB V MEMBUAT MATERI UJI/SOAL

BAB VI PENSKORAN

BAB VII APLIKASI GO TO

BAB VIII MENCARI SKOR AKHIR

c) Materi

Materi merupakan inti dari isi buku, pada bagian ini disajikan dalam bentuk uraian yang dilengkapi dengan visualisasi gambar sehingga mahasiswa lebih mudah memahami materi.

3. Tahap Pengembangan (Develop)

Tujuan tahap ini adalah untuk menghasilkan buku teks yang sudah direvisi berdasarkan masukan dari para pakar dan hasil respon mahasiswa. Tahap pengembangan (develop) meliputi dua fase:

a. Penilaian ahli (expert appraisal) yaitu validasi perangkat oleh para pakar diikuti dengan revisi.
Pada tahap ini, peneliti melakukan validasi produk dengan menggunakan angket validasi yang diberikan kepada para ahli atau validator. Validator yang dipilih adalah ahli matematika, ahli pembelajaran, dan ahli media IT. Selain memberikan penilaian, validator juga memberikan tanggapan, kritik dan saran terhadap Buku LI yang telah dikembangkan. Setelah data hasil validasi diperoleh, selanjutnya dilakukan analisis data berdasarkan teknik analisis data yang telah diuraikan pada bab III. Pada validasi produk ini, tabel 1 menggambarkan hasil analisis data mengenai kevalidan buku teks matematika berbasis IT berdasarkan tiga orang validator.

Tabel 1. Hasil Validasi Ahli Materi

\begin{tabular}{|c|c|c|c|c|c|}
\hline \multirow[t]{2}{*}{ No } & \multirow[t]{2}{*}{ Aspek yang dinilai } & \multicolumn{3}{|c|}{$\begin{array}{l}\text { Validator } \\
\text { ke- }\end{array}$} & \multirow[t]{2}{*}{$A_{i}$} \\
\hline & & 1 & 2 & 3 & \\
\hline 1. & Bahasa Lugas & 3 & 3 & 3 & 3 \\
\hline 2. & Bahasa komunikatif & 3 & 3 & 3 & 3 \\
\hline 3. & $\begin{array}{l}\text { Bahasa mudah } \\
\text { dipahami }\end{array}$ & 3 & 3 & 3 & 3 \\
\hline 4. & $\begin{array}{l}\text { Bahasa sesuai } \\
\text { dengan sifat bahasa } \\
\text { matematika }\end{array}$ & 3 & 4 & 3 & 3,3 \\
\hline 5. & $\begin{array}{l}\text { Istilah dan simbol } \\
\text { yang digunakan } \\
\text { konsisten. }\end{array}$ & 3 & 4 & 3 & 3,3 \\
\hline 6. & $\begin{array}{l}\text { Sesuai dengan } \\
\text { kaidah bahasa }\end{array}$ & 4 & 4 & 4 & 4 \\
\hline \multicolumn{5}{|c|}{$\mathrm{RTV}=\frac{\sum A_{i}}{6}$} & 19,6 \\
\hline & & & & & 3.26 \\
\hline
\end{tabular}

Berdasarkan Tabel 1, rata-rata penilaian dari tiga orang validator terhadap Buku LI adalah sebesar 3, 26. Hal ini menunjukkan bahwa, Buku LI tersebut telah memenuhi kriteria kevalidan yaitu berada pada rentang $3 \leq$ $R T V \leq 4$.

Adapun kesalahan yang harus diperbaiki oleh penulis adalah letak-letak gambar yang ada di buku LI kurang proposional dan belum ada namanya. Oleh sebab itu harus diproposionalkan. Proposionalisme gambar sangat berpengaruh terhadap persepsi pembaca dalam memahami LI.

b. Pengujian Pengembangan (developmental testing) yaitu Uji Coba Terbatas Dengan Mahasiswa yang Sesungguhnya.

Tahap uji coba terbatas ini dilakukan terhadap satu kelas saja yaitu kelas TMT 4B. hasil uji coba terbatas ini dilakukan untuk 
melihat keefektifan Buku LI. Keefektifan Buku LI dilihat berdasarkan hasil tes akhir mahasiswa dan hasil analisis angket respon mahasiswa setelah menggunakan Buku LI

1) Hasil Tes Akhir Mahasiswa

Hasil tes akhir mahasiswa ujicoba kelompok kecil dapat dilihat pada tabel berikut.

Tabel 2. Rekapitulasi Hasil Tes Akhir Mahasiswa Kelompok Kecil

\begin{tabular}{lc}
\hline & Kelas kecil \\
\hline $\begin{array}{l}\text { Persentase Jumlah Mahasiswa } \\
\text { yang Mendapat Nilai Lebih } \\
\text { dari } 80\end{array}$ & $100 \%$ \\
\hline
\end{tabular}

Hasil persentase Tes Akhir mahasiswa yang mendapat nilai lebih dari 80 sebesar 100\%. hal ini berarti hasil belajar mahasiswa yang kuliah dengan menggunakan Buku LI dikatakan tuntas.

2) Hasil Angket Respon Mahasiswa

Berdasarkan hasil analisis respon mahasiswa terhadap Buku LI pada uji coba kelompok kecil terdapat $85.71 \%$ atau sekitar 30 orang mahasiswa yang memberi respon positif. Dengan demikian, berdasarkan kriteria, pada uji coba kelompok kecil ini mahasiswa telah merespon positif penggunaan Buku LI. Karena keberhasilan inilah maka aktivitas dilanjutkan pada uji coba kelompok besar dengan tujuan untuk memperoleh hasil yang lebih optimal lagi.

4. Tahap Pendiseminasian (Disseminate)

Tahap ini merupakan tahap penggunaan buku LI yang telah dikembangkan pada skala yang lebih luas, misalnya di kelas lain. Tujuan lain adalah untuk menguji efektivitas penggunaan perangkat di dalam perkuliahan. Pada tahap pendiseminasian ini peneliti juga hanya menguji kefektifan Buku LI seperti uji coba pada kelompok kecil. Perbedaannya pada tahap pendiseminasian ini kelas yang digunakan untuk uji coba lebih banyak, yaitu TMT 4A, 4C, 4D, 4E, 4F.

a. Hasil Tes Akhir Mahasiswa TMT 4A

Rekapitulasi hasil tes akhir mahasiswa disajikan dalam tabel 3 berikut ini.

Tabel 3. Rekapitulasi Hasil Tes Akhir Mahasiswa TMT A

\begin{tabular}{|c|c|}
\hline & $\begin{array}{l}\text { Kelas } \\
\text { AMT }\end{array}$ \\
\hline $\begin{array}{l}\text { Persentase Jumlah } \\
\text { mahasiswa yang mendapat } \\
\text { nilai lebih dari } 80\end{array}$ & $97.6 \%$ \\
\hline
\end{tabular}

Hasil persentase Tes Akhir mahasiswa TMT A yang mendapat nilai lebih dari 80 sebesar $97.6 \%$. Hal ini berarti hasil belajar mahasiswa yang kuliah dengan menggunakan Buku LI dikatakan tuntas.

b. Hasil Angket respon mahasiswa TMT 4A

Berdasarkan hasil analisis respon mahasiswa TMT 4A terhadap Buku LI adalah $89.7 \%$ atau 35 orang mahasiswa yang memberi respon positif. Dengan demikian, berdasarkan kriteria, pada ujicoba mahasiswa TMT 4A diperoleh hasil bahwa mahasiswa telah merespon positif penggunaan Buku LI.

c. Hasil Tes Akhir Mahasiswa TMT 4C

Hasil tes akhir mahasiswa TMT 4C dapat dilihat dalam tabel 4 berikut.

Tabel 4. Rekapitulasi Hasil Tes Akhir Mahasiswa TMT C

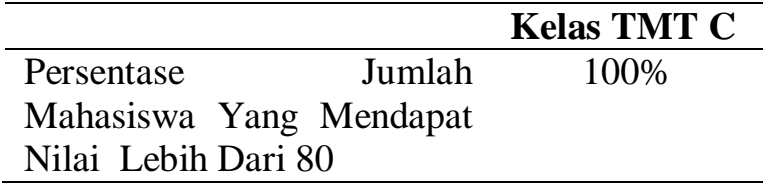

Hasil persentase Tes Akhir mahasiswa TMT C yang mendapat nilai lebih dari 80 sebesar $100 \%$. Hal ini berarti hasil belajar mahasiswa yang kuliah dengan menggunakan Buku LI dikatakan tuntas.

d. Hasil Angket respon mahasiswa TMT 4C

Berdasarkan hasil analisis respon mahasiswa TMT 4C terhadap Buku LI adalah 94.9\% atau 37 orang mahasiswa yang memberi respon positif. Dengan demikian menurut kriteria, uji coba mahasiswa TMT 4C memperoleh hasil bahwa mahasiswa telah merespon positif penggunaan Buku LI.

e. Hasil Tes Akhir Mahasiswa TMT 4D

Rekapitulasi hasil tes akhir mahasiswa TMT D dapat dilihat dalam tabel 5 berikut.

Tabel 5. Rekapitulasi Hasil Tes Akhir Mahasiswa TMT D

\begin{tabular}{lrc}
\hline & & Kelas TMT D \\
\hline Persentase & Jumlah & $95.2 \%$ \\
Mahasiswa & yang & \\
$\begin{array}{l}\text { Mendapat } \\
\text { dari } 80\end{array}$ & Lebilai & \\
\hline
\end{tabular}

Hasil persentase Tes Akhir mahasiswa TMT D yang mendapat nilai lebih dari 80 sebesar 95.2\%. Hal ini berarti hasil belajar mahasiswa yang kuliah dengan menggunakan Buku LI dikatakan tuntas. 
f. Hasil Angket respon mahasiswa TMT 4D

Berdasarkan hasil analisis respon mahasiswa TMT 4D terhadap Buku Teks Matematika Berbasis IT adalah 95.2\% atau 40 mahasiswa yang memberi respon positif. Dengan demikian menurut kriteria, mahasiswa TMT 4D telah merespon positif penggunaan Buku LI.

g. Hasil Tes Akhir Mahasiswa TMT 4E

Rekapitulasi hasil tes akhir mahasiswa disajikan dalam tabel 6 berikut.

Tabel 6. Rekapitulasi Hasil Tes Akhir Mahasiswa TMT E

\begin{tabular}{lc}
\hline & \multicolumn{1}{c}{ Kelas TMT } \\
E \\
\hline Persentase Jumlah mahasiswa & $100 \%$ \\
yang mendapat nilai lebih dari & \\
80 & \\
\hline
\end{tabular}

Hasil persentase Tes Akhir mahasiswa TMT E yang mendapat nilai lebih dari 80 sebesar $100 \%$. Hal ini berarti hasil belajar mahasiswa yang kuliah dengan menggunakan Buku LI dikatakan tuntas.

h. Hasil Angket respon mahasiswa TMT 4E

Berdasarkan hasil analisis respon mahasiswa TMT 4E terhadap Buku LI, 95.5\% atau 43 mahasiswa memberi respon positif. Dengan demikian menurut kriteria, mahasiswa TMT 4E telah merespon positif penggunaan Buku LI.

i. Hasil Tes Akhir Mahasiswa TMT 4F

Rekapitulasi hasil tes akhir mahasiswa disajikan dalam tabel 7.

Tabel 7. Rekapitulasi Hasil tes Akhir Mahasiswa TMT F

\begin{tabular}{lc} 
& KelasTMT \\
& F \\
Persentase Jumlah mahasiswa & $97.4 \%$ \\
yang mendapat nilai lebih dari & \\
80 & \\
\hline
\end{tabular}

Hasil persentase Tes Akhir mahasiswa TMT $F$ yang mendapat nilai lebih dari 80 sebesar $97.4 \%$. Hal ini berarti hasil belajar mahasiswa yang kuliah dengan menggunakan Buku LI dikatakan tuntas.

j. Hasil Angket respon mahasiswa TMT 4F

Berdasarkan hasil analisis respon mahasiswa TMT 4F terhadap Buku LI adalah 94.7\% atau 34 mahasiswa yang memberi respon positif. Dengan demikian menurut kriteria, pada uji coba mahasiswa TMT 4F diperoleh hasil bahwa mahasiswa telah merespon positif penggunaan LI.

Untuk selanjutnya hasil analisis Tes akhir mahasiswa dan hasil Respon mahasiswa terhadap penggunaan Buku LI direkapitulasi seperti tabel 8 dan 9 di bawah ini.

Tabel 8. Rekapitulasi Rata-Rata Hasil Tes Akhir Mahasiswa

\begin{tabular}{lrl}
\hline & $\begin{array}{l}\text { Kelompok } \\
\text { kecil }\end{array}$ & $\begin{array}{l}\text { Kelas } \\
\text { besar }\end{array}$ \\
\hline $\begin{array}{l}\text { Persentase Jumlah } \\
\text { mahasiswa yang mendapat }\end{array}$ & $100 \%$ & 98.4 \\
nilai lebih dari 80 & & $\%$ \\
\hline
\end{tabular}

Tabel 9. Rekapitulasi Rata-rata Hasil Angket Respon Mahasiswa

\begin{tabular}{lccc}
\hline & $\begin{array}{l}\text { Kelompo } \\
\text { k kecil }\end{array}$ & $\begin{array}{l}\text { Kela } \\
\text { s } \\
\text { besar }\end{array}$ \\
\hline $\begin{array}{l}\text { Persentase } \\
\text { mahasiswa } \\
\text { memberi respon positif }\end{array}$ & & $94 \%$ \\
\hline
\end{tabular}

\section{SIMPULAN} hal, yaitu

Pada bagian ini akan dikemukakan dua 1. Ketercapaian Tujuan Penelitian

a. Kevalidan

Berdasarkan hasil uji kevalidan yang telah dikemukakan pada hasil paparan data bahwa Buku Lectora Inspire (LI) telah memenuhi kriteria kevalidan berdasarkan penilaian ahli yaitu sebesar 3.26.

b. Keefektifan

Keefektifan Buku LI ditentukan oleh 2 hal, yaitu tes akhir mahasiswa dan respons mahasiswa terhadap Buku LI. Dari hasil analisis terhadap tes akhir mahasiswa dan angket respon positif mahasiswa kelompok kecil dan kelompok besar yang terdiri dari kelas $4 \mathrm{~A}, 4 \mathrm{~B}, 4 \mathrm{C}, 4 \mathrm{D}$, dan $4 \mathrm{~F}$, serta berdasarkan kriteria keefektivan, buku LI dapat dikatakan efektif.

2. Temuan-temuan khusus

Temuan-temuan khusus yang penting dalam penelitian ini adalah sebagai berikut:

a. Penggunaan Buku LI di dalam perkuliahan Pembelajaran Matematika berbasis IT mampu membuat mahasiswa selalu aktif belajar secara otodidak untuk dapat mengaplikasikan software Lectora Inspire dengan benar 
PRINSIP Pendidikan Matematika

Volume 1, Nomor 2, Mei 2019

b. Dosen berperan sebagai pembimbing dituntut untuk mampu mengarahkan dan menjadi sumber utama di dalam mendapatkan informasi tentang bagaimana belajar software Lectora Inspire .

\section{DAFTAR PUSTAKA}

Majid, A. (2011). Perencanaan Pembelajaran:

Mengembangkan Standar Kompetensi

Guru. Bandung: Remaja Rosdakarya

Mas'ud, M. (2014). Membuat Multimedia Pembelajaran Dengan Lectora. Yogyakarta: Pustaka Shonif
Muslich, M. (2010). Textbook Writing, DasarDasar Pemahaman, Penulisan, dan Pemakaian Buku Teks. Yogyakarta: ArRuzz Media.

Sugiyono. (2011). Metode Penelitian Kuantitatif, Kualitatif, dan $R \& D$. Bandung: Alfabeta

Sungkono, dkk. (2003). Pengembangan Bahan Ajar. Yogyakarta: FIP UNY

Tarigan, H.G., dan Tarigan, D. (2009). Telaah Buku Teks Bahasa Indonesia. Bandung: Angkasa, 13 